\title{
Dissociation, schizotypy, and fantasy proneness in undergraduate student
}

Citation for published version (APA):

Merckelbach, H. L. G. J., Rassin, E. G. C., \& Muris, P. E. H. M. (2000). Dissociation, schizotypy, and fantasy proneness in undergraduate student. Journal of Nervous and Mental Disease, 188(7), 188-7. https://doi.org/10.1097/00005053-200007000-00006

Document status and date:

Published: 01/01/2000

DOI:

10.1097/00005053-200007000-00006

Document Version:

Publisher's PDF, also known as Version of record

\section{Please check the document version of this publication:}

- A submitted manuscript is the version of the article upon submission and before peer-review. There can be important differences between the submitted version and the official published version of record.

People interested in the research are advised to contact the author for the final version of the publication, or visit the DOI to the publisher's website.

- The final author version and the galley proof are versions of the publication after peer review.

- The final published version features the final layout of the paper including the volume, issue and page numbers.

Link to publication

\footnotetext{
General rights rights.

- You may freely distribute the URL identifying the publication in the public portal. please follow below link for the End User Agreement:

www.umlib.nl/taverne-license

Take down policy

If you believe that this document breaches copyright please contact us at:

repository@maastrichtuniversity.nl

providing details and we will investigate your claim.
}

Copyright and moral rights for the publications made accessible in the public portal are retained by the authors and/or other copyright owners and it is a condition of accessing publications that users recognise and abide by the legal requirements associated with these

- Users may download and print one copy of any publication from the public portal for the purpose of private study or research.

- You may not further distribute the material or use it for any profit-making activity or commercial gain

If the publication is distributed under the terms of Article $25 \mathrm{fa}$ of the Dutch Copyright Act, indicated by the "Taverne" license above, 


\title{
Dissociation, Schizotypy, and Fantasy Proneness in Undergraduate Students
}

\author{
HARALD MERCKELBACH, Ph.D., ${ }^{1}$ ERIC RASSIN, Ph.D., ${ }^{1}$ and PETER MURIS, Ph.D. ${ }^{1}$
}

\begin{abstract}
Previous research has noted a robust correlation between dissociation and schizophrenia-like symptoms. One way to interpret the relationship between dissociation and schizotypy is to assume that it is an artifact of fantasy proneness. In the present study, 152 undergraduates completed measures of dissociation, schizotypy, and fantasy proneness. Dissociative tendencies were found to be related to the full range of schizotypal features. Regression analysis showed that schizotypy still contributed to the prediction of dissociative tendencies when variance related to fantasy proneness was extracted. These results indicate that the close connection between dissociation and schizotypy cannot be interpreted in terms of an artifact produced by fantasy proneness. Thus, the overlap between dissociation and schizotypy warrants systematic study.
\end{abstract}

- J Nerv Ment Dis 188:428-431, 2000

Dissociation is commonly defined as "a disruption in the usually integrated functions of consciousness, memory, identity, or perception of the environment" (American Psychiatric Association, 1994; DSM-IV; p. 477). With such a broad definition, it is not surprising that dissociation has been linked to a wide variety of traits and psychiatric conditions. Thus, dissociative tendencies have been found to be associated with fantasy proneness (e.g., Rauschenberger and Lynn, 1995), neuroticism (Johnson et al., 1995), negative affectivity (Irwin, 1995), eating disorders (Vanderlinden et al., 1993), psychosomatic complaints (Engel et al., 1996), and trauma-related psychopathology (Nijman et al., 1999; Tichenor et al., 1996). Indeed, some authors have argued that the concept of dissociation is in danger of becoming meaningless precisely because it is implicated in what seem to be highly diverse phenomena (Frankel, 1996).

Meanwhile, a close look at the literature shows that apart from their obvious involvement in the dissociative disorders (e.g., dissociative fugue, depersonalization disorder), dissociative tendencies are especially strongly linked to schizophrenia-like symptoms. This close connection between dissociation and schizotypy has been repeatedly documented in both nonclinical and clinical samples. For example, Bauer and Power (1995) found a correlation of .57 between dissociative tendencies and schizotypal traits in their nonclinical sample. This substantial correlation was replicated in a study by

\footnotetext{
${ }^{1}$ Department of Experimental Psychology, Maastricht University, The Netherlands. Send reprint requests to Dr. $H$. Merckelbach, Department of Experimental Psychology, P.O. Box 616, 6200 MD Maastricht, The Netherlands.
}

Irwin (1998). Likewise, Lipsanen et al. (1999) recently noted that normal individuals who report micropsychotic experiences in the visual domain (i.e., visual distortions) score higher on an index of dissociative tendencies compared to individuals who do not report such experiences. Allen and Coyne (1995) examined MMPI profiles of patients with trauma-related psychopathology. They concluded that dissociative tendencies correlate with several MMPI scales, but that the correlation with the schizophrenia-subscale of the MMPI was highest.

The question arises how the close link between dissociative tendencies and schizotypal traits can best be interpreted. One possibility is that it is fully mediated by another strong correlate of dissociation, namely fantasy proneness (Merckelbach et al., 1999; Rauschenberger and Lynn, 1995). Note that fantasy proneness per se is a benign trait. Yet, in the context of self-report questionnaires, this trait may contribute to artifactual links. That is, individuals scoring high on fantasy proneness tend to report relatively rare and exotic events (e.g., Merckelbach et al., 2000). Self-report scales tapping schizophrenia-like symptoms contain, almost by definition, many items that refer to unusual experiences. Thus, a response set to endorse unusual items might be critically involved in the correlation between dissociation and schizotypy. The finding that fantasy proneness, dissociation, and schizotypy all have been found to be related to self-reports of paranormal experiences (e.g., Irwin, 1990; Ross and Joshi, 1992; Thalbourne, 1994) underlines this possibility. Psychometric studies showing that dissociative patients often score high on fake bad scales of, e.g., the MMPI can also be taken as suggestive support 
for the idea that self-reports of high dissociators should be interpreted with caution, although alternative accounts of these psychometric findings have been formulated (e.g., Allen et al., 1997).

Plainly, the close links between dissociation, schizotypy, and other schizophrenia-like phenomena (e.g., micropsychotic experiences; Lipsanen et al., 1999) would be of a limited clinical significance if they can be fully accounted for in terms of a tendency to report unusual experiences on the basis of fantasy proneness. With this in mind, the current study sought to examine the precise connections between dissociative tendencies, schizotypal traits, and fantasy proneness in a nonclinical sample. More specifically, the study investigated to what extent the link between dissociation and schizotypy remains intact when the contribution of fantasy proneness is partialled out.

\section{Methods}

\section{Participants}

The sample consisted of 152 first-year psychology students ( 33 men) who volunteered to participate in the study. Their mean age was 19.1 years (range: 17 to 28 years). Participants received a small financial compensation for completing a set of questionnaires (see below). Questionnaires were administered during a mass testing session at which research assistants were present to provide clarification if necessary.

\section{Measures}

Participants completed the Dissociative Experiences Scale (DES; Bernstein and Putnam, 1986), the Claridge Schizotypal Personality Scale (STA; Claridge and Broks, 1984), and the Creative Experiences Questionnaire (CEQ; Merckelbach et al., 1998), an index of fantasy proneness. The DES is a 28-items self-report instrument that lists a number of dissociative phenomena (e.g., amnesia, absorption, depersonalization, derealization). Examples of DES items include feeling as if one's body is not one's own and becoming so absorbed in a movie that one is unaware of what is happening. Respondents indicate on 100-mm visual analog scales (anchors: $0=$ never; $100=$ all the time) the degree to which they experience these phenomena in daily life. Total DES scores are obtained by averaging across the 28 items, with higher total DES scores indicating a higher frequency of dissociative phenomena. There is a large body of evidence showing that the test-retest stability and internal consistency of the DES are excellent (Van IJzendoorn and
Schuengel, 1996). Also, a number of studies have found that patients with dissociative disorders (dissociative identity disorder, dissociative amnesia, depersonalization disorder) have significantly higher DES scores than patients with other diagnoses (e.g., anxiety disorders, eating disorders), a finding that has been interpreted as support for the validity of the DES (e.g., Bernstein and Putnam, 1986).

Schizotypal traits were measured with the STA (Claridge and Broks, 1984), a scale consisting of 37 Yes-No items that are closely modelled on DSM criteria for schizotypal personality. Thus, STA primarily taps the cognitive and social anxiety-aspects of schizotypy (e.g., Bentall et al., 1989). Psychometric properties of the STA are sound and factor analytic studies have revealed that it contains three major dimensions (Hewitt and Claridge, 1989): magical thinking (e.g., "Are you sometimes sure that other people can tell what you are thinking?"); unusual perceptual experiences (e.g., "Do you ever feel that your thoughts really don't belong to you?"); and paranoid ideation and suspiciousness (e.g., "Do you sometimes feel that people are talking about you?"). Yes-answers are summed to obtain subscale scores and a total score, with higher scores indicating a higher frequency of schizophrenia-like symptoms.

The CEQ (Merckelbach et al., 1998) is a Dutch instrument for measuring fantasy proneness. It comprises 25 dichotomous items that were derived from extensive case descriptions of fantasy proneness provided by Wilson and Barber (1983). Typical examples are: "In general, I spend at least half of the day fantasizing or daydreaming"; "My fantasies are so vivid that they are like a good movie"; and "I tend to confuse my fantasies with memories of real events." CEQ's internal and test-retest reliabilities are sound, and the scale correlates strongly with concurrent measures of fantasy proneness (Merckelbach et al., 1998).

\section{Results}

Cronbach's alphas for DES, STA, and CEQ were $.92, .86$, and .73 , respectively, showing that the internal consistency of the instruments was satisfactory. Mean scores for DES, STA, and CEQ were 18.2 $(\mathrm{SD}=11.5), 13.1(\mathrm{SD}=6.5)$, and $8.3(\mathrm{SD}=4.2)$. Note that these scores come close to average DES, STA, and CEQ values previously reported for nonclinical samples (e.g., Bentall et al., 1989; Merckelbach et al., 1999, 2000).

Table 1 shows the Pearson product-moment correlations between DES, STA, and CEQ. Correlations with separate STA dimensions are also shown. As can be seen, DES correlated positively and signifi- 
TABLE 1

Pearson Correlations between Dissociation (DES), Schizotypy Measures (Total STA, Magical Thinking, Unusual Perception, and Paranoid Ideation), and Fantasy Proneness ( $C E O ; \mathrm{N}=152$ )

\begin{tabular}{llll}
\multicolumn{4}{c}{ and Fantasy Proneness $(C E O ;=152)$} \\
\hline CEQ & DES & CEQ & Total STA \\
Total STA & $.53^{*}$ & & \\
Magical thinking & $.64^{*}$ & $.61^{*}$ & \\
Unusual perception & $.52^{*}$ & $.52^{*}$ & $.77^{*}$ \\
Paranoid ideation & $.60^{*}$ & $.56^{*}$ & $.83^{*}$ \\
\hline
\end{tabular}

${ }^{*} p<.01$ (two-tailed).

cantly with both fantasy proneness (CEQ) and schizotypy (STA). Interestingly, the significant association between DES and schizotypy was evident for all three STA dimensions. The same was true for the connection between fantasy proneness and STA. The correlation between DES and schizotypy remained significant when the contribution of fantasy proneness was statistically removed. Thus, the partial $r$ between DES and STA while controlling for CEQ was $.47(p<.01)$. Similarly, the partial $r$ 's between DES and the separate subscales of STA were all positive and significant when the contribution of fantasy proneness was partialled out (all $r$ 's $>.25$; all $p$ 's $<.01$ ). The partial correlation between DES and CEQ while controlling for STA was also significant: $r=.23, p<.01$. This pattern of partial correlations shows that fantasy proneness and schizotypy are independent correlates of dissociation. This point is underscored by stepwise multiple regression analysis involving DES as the dependent variable and CEQ and STA as predictors. When CEQ was entered on the first step $\left(R^{2}=.28 ; F[1,150]=59.5, p<.01\right)$, entry of STA in the second step increased $R^{2}$ to .44 $(F[1,149]=42.6, p<.01)$, indicating that after removal of DES variance attributable to fantasy proneness, schizotypy still contributed to the prediction of DES.

\section{Discussion}

The main findings of the present study can be catalogued as follows. To begin with, there were robust correlations between dissociative tendencies, schizotypy, and fantasy proneness. These correlations replicate earlier work in which dissociative tendencies were found to be related to fantasy proneness (Merckelbach et al., 1999; 2000; Rauschenberger and Lynn, 1995) and schizotypy (Allen and Coyne, 1995; Bauer and Power, 1995; Irwin, 1998). Second, dissociative tendencies were associated with several distinct aspects of schizotypy. That is, dissociation was not only linked to the magical thinking dimension of schizotypy, but also to the unusual perception and paranoid ideation components of schizotypy. Third, even when the contribution of fantasy proneness was statistically removed, the correlation between dissociation and schizotypy remained significant. This finding indicates that the link between dissociation and schizotypy is not carried by fantasy proneness.

One obvious characteristic of individuals scoring high on fantasy proneness is their tendency to display a positive response bias. Thus, fantasy proneness enhances vulnerability to memory distortions (e.g., Hyman and Billings, 1998) and confabulations (e.g., Merckelbach et al., 2000; Merckelbach and Muris, in press). Following this line of reasoning, one could speculate that the close association between dissociation and schizophrenia-like symptoms (e.g., visual distortions; Lipsanen et al., 1999) is an artificial by-product of fantasy prone individuals' inclination to overreport or exaggerate unusual experiences (e.g., paranormal experiences). However, the present findings cast doubts on such an explanation in that they show that the link between dissociation and schizotypy can not be accounted for in terms of fantasy proneness. Based on clinical data, some authors have suggested that the poor reality testing implicated in intense absorption might be responsible for the overlap between dissociation and schizotypy (e.g., Allen et al., 1997). Keeping in mind that there is a high degree of equivalence between absorption and fantasy proneness (Kihlstrom et al., 1994), the present data do not support this position either. The current results are more in line with the idea that dissociation and schizotypy are related to each other because they share a set of highly specific features that have to do with lack of cognitive control. Indeed, inspection of individual DES and STA items makes clear that many of them pertain to experiences that involve memory and/or perceptual failures. Clearly, clinical studies are needed to clarify the precise nature of these cognitive failures.

In sum, then, the current study demonstrates that the relationship between dissociation and schizotypy is not an artifact of fantasy proneness. Although the generalizability of the present findings to clinical populations remains to be established, they raise new issues about the intertwining of dissociation and symptoms in the schizophrenia spectrum. Much of the literature on diagnosing dissociative disorders assumes that dissociative and schizophrenic symptoms correspond to distinct nosologic categories and that superficial overlap between these symptoms may lead to a misdiagnosis of schizophrenia in patients with a dissociative disorder. Yet, the current results as well as clinical data 
of Allen and Coyne (1995) suggest that the overlap between dissociation and schizophrenia may be more profound and warrants systematic study.

\section{References}

Allen JG, Coyne L (1995) Dissociation and vulnerability to psychotic experience: The dissociative experience scale and the MMPI-2. J Nerv Ment Dis 183:615-622.

Allen JG, Coyne L, Console DA (1997) Dissociative detachment relates to psychotic symptoms and personality decompensation. Compr Psychiatry 38:327-334.

American Psychiatric Association (1994) Diagnostic and statistical manual of mental disorders (4th ed). Washington DC: Author.

Bauer AM, Power KG (1995) Dissociative experiences and psychopathological symptomatology in a Scottish sample. Dissociation 8:209-219.

Bentall RP, Claridge GS, Slade PD (1989) The multidimensional nature of schizotypal traits: A factor analytic study with normal subjects. Br J Clin Psychol 28:363-375.

Bernstein EM, Putnam F'W (1986) Development, reliability, and validity of a dissociation scale. $J$ Nerv Ment Dis 174:727-735.

Claridge G, Broks P (1984) Schizotypy and hemisphere function: Theoretical considerations and the measurement of schizotypy. Pers Individ Diff 5:633-648.

Engel CG, Walker EA, Katon WJ (1996). Factors related to dissociation among patients with gastrointestinal complaints. $J$ Psychosom Res 40:643-653.

Frankel FH (1996) Dissociation: The clinical realities. Am J Psychiatry (Festschrift Suppl) 153:64-70.

Hewitt JK, Claridge G (1989) The factor structure of schizotypy in a normal population. Pers Individ Diff 10:323-329.

Hyman IE, Billings FJ (1998). Individual differences and the creation of false memories. Memory 6:1-20.

Irwin HJ (1990). Fantasy proneness and paranormal beliefs. Psychol Rep 66:655-658.

Irwin HJ (1995) Affective predictors of dissociation, III: Affect balance. J Psychol 129:463-467.

Irwin HJ (1998). Dissociative tendencies and the sitting duck: Are self-reports of dissociation and victimization symptomatic of neuroticism? J Clin Psychol 54:1005-1015.

Johnson RC, Edman JL, Danko GP (1995) Self reported experiences and dissociation. Person Individ Diff 18:793-795.
Kihlstrom JF, Glisky ML, Angiulo MJ (1994). Dissociative tendencies and dissociative disorders. $J$ Abnorm Psychol 103: 117-124.

Lipsanen T, Lauerma H, Peltola P, Kallio S (1999) Visual distortions and dissociation. of Nerv Ment Dis 187:109-112

Merckelbach H, Muris P (in press) The causal link between selfreported trauma and dissociation: A critical review. Behav Res Ther.

Merckelbach H, Muris P, Horselenberg R, Stougie S (2000) Dissociative experiences, response bias, and fantasy proneness in college students. Person Individ Diff 28:49-58.

Merckelbach H, Muris P, Rassin E (1999) Fantasy proneness and cognitive failures as correlates of dissociative experiences. Person Individ Diff 26:961-967.

Merckelbach H, Muris P, Schmidt H, Rassin E, Horselenberg $\mathrm{R}$ (1998) De Creatieve Ervaringen Vragenlijst als maat voor "fantasy proneness" [The Creative Experiences Questionnaire (CEQ) as a measure of fantasy proneness]. De Psycholoog 33:204-208.

Nijman H, Dautzenberg M, Merckelbach H, Jung P, Wessel I, Campo J (1999) Self-mutilating behavior of psychiatric inpatients. Eur Psychiatry 14:4-10.

Rauschenberger SL, Lynn SJ (1995). Fantasy proneness, DSMIII-R axis I psychopathology, and dissociation. J Abnorm Psychol 104:373-380.

Ross CA, Joshi S (1992) Paranormal experiences in the general population. J Nerv Ment Dis 180:357-361.

Thalbourne MA (1994) Belief in the paranormal and its relationship to schizophrenia-relevant measures: A confirmatory study. Br J Clin Psychol 33:78-80.

Tichenor V, Marmar CR, Weiss DS, Metzler TJ, Ronfeldt HM (1996) The relationship of peritraumatic dissociation and posttraumatic stress: Findings in female Vietnam theater veterans. $J$ Consult Clin Psychol 64:1054-1059.

Vanderlinden J, Vandereycken W, Van Dyck R (1993) Dissociative experiences and trauma in eating disorders. Int $J$ Eating Disord 13:187-193.

Van IJzendoorn $\mathrm{MH}$, Schuengel $\mathrm{C}$ (1996) The measurement of dissociation in normal and clinical populations: Meta-analytic validation of the Dissociative Experiences Scale (DES). Clin Psychol Rev 16:365-382.

Wilson SC, Barber TX (1983) Fantasy-prone personality: Implications for understanding imagery, hypnosis, and parapsychological phenomena. In AA Sheikh (Ed). Imagery: Current theory, research, and application (pp 340-387). New York: Wiley. 